Publisher homepage: www.universepg.com, ISSN: 2707-4625 (Online) \& 2707-4617 (Print)

https://doi.org/10.34104/ijmms.021.0850100

International Journal of Material and Mathematical

Sciences

Journal homepage: www.universepg.com/journal/ijmms

\title{
An analysis on the job preference of Jatiya Kabi Kazi Nazrul Islam University Students
}

\section{Lutfunneher*}

Department of Economics, Jatiya Kabi Kazi Nazrul Islam University, Trishal, Mymensingh.

*Correspondence: luttfunnahar@gmail.com (Lecturer, Department of Economics, Jatiya Kabi Kazi Nazrul Islam University, Trishal, Mymensingh).

\section{ABSTRACT}

This study examined the job preference among students of different subjects of different faculties in the campus of Jatiya Kabi Kazi Nazrul Islam University, Trishal, Mymensingh. Qualitative variables and variables which are quantitative in nature have been used for this study. We have chosen the topic job preference of students of the different faculties because now-a-days every sector for a job is strict about their rules and regulations. At present time students are frustrated about the lengthy process of jobs and dissimilarities between academic studies and job conditions. The main aims and objectives of this study were to find out information about the job preference of University students in Bangladesh. The research ensured the following objectives; such as Known about the present condition of job preference of Jatiya Kabi Kazi Nazrul Islam University. Found out and identified factors affecting their Job Preference. So the aims and objectives of this research contained various issues. Such as knowing how many students are expected, how many students want to be an entrepreneur, and how many students are going to be a foreign country for a job. Study of the plan decorated sequentially.

Keywords: Job preference, Study, Students, University, Career, Knowledge, Faculties, Sample, and Data.

\section{INTRODUCTION:}

Not much research has been done before on job expectations of students in Bangladesh. Choosing a career from many options is an important decision for shaping human life. It helps one to achieve his life goal. Despite being such an important subject, not much research has been done on it before. Many universities abroad have done research on this. There have been different types of research at different times based on this topic. Scholars and researchers from around the world have taken this as an important field for their research and have found many professions that influence their career choices or expectations. We all have desires or dreams to succeed in the workplace. Everyone wants to move UniversePG I www.universepg.com from that job to a successful career after getting the expected job.

\section{Review of the Literature}

Literary review was very important subject for any research. And for this, this work has to be done first. By reviewing the literature of our research we enabled to learn about other topics and make it easier to do our research based on that. As it could be said, by reviewing the literature we could find out what has been done and what had not been done in the past. And we tried to fill in the gaps in this type of research. Literary review creates a gap between past and present knowledge that helped us complete our research. Through 
literature review we will get an idea of different areas of our research as oppose to different quotes, arguments, thematic methods, approaches, topics and debates, which helped us in our research. Also which argument of literature was more persuasive and why persuaded? I analyzed it.... (Ahmed, 2017, academia, para. 2). We also argued which one of the various methods we will discuss is more appropriate. We also collected information from various newspaper websites or magazines, book, internet etc. to review the literature of our research and try to explain or critique it, which will be helpful in understanding or completing our research.

Below we presented some of the literatures or quotes from prominent people who played an important role in our research. So these are given below: In engineering education, career preparation courses may be included so as to prepare students adequately for their first job, future careers, and to reinforce career decision-making skills (Proches et al., 2018). First, focusing on ranking methods, lacovou opinions, he analyzed job preferences of undergraduate business and MBA students at a public university in the USA. Students emphasized on growth potential as their attribute and followed by a benefits package, job responsibility, job variety or complexity and work flexibility founded by researchers (Iacovou et al., 2011). Comparative analysis about various professions, (Rosen et al., 1982) detected high parental influence and satisfaction on professions such as medical, attomey, engineer and accountants.

Parental influences are the vital medium to set up the future goals, interests, actions and accomplishments for their children during academic period. Similarly, (Ferreira et al., 2006) indicated that with the other various factors parental influences also responsible for good behavior of teenagers. It also used the ranking method, 9 analyzing preferences of chemical engineering students. The most important attribute found was the type of work, followed by advancement opportunities. Some academician worked with internal factors, including the personal attitude and educations quality with family background; enteral factors including market, job opportunities and job facilities, inceptives and advancement etc. and impact of those to choice of career (Felton et al., 1994; Paolillo \& Estes, 1992). (Barnet, 2007) stated the view that, like parents the im-pact of UniversePG I www.universepg.com teachers is also noteworthy. Anana and Nique, (2010) stressed that personal values is a key standard in career choice. Individuals have different interest and preference about their future career. Every person motivated by their cherished dream. (Singaravelu et al., 2005; Cutler et al., 2006; Gati et al., 2011) are also important elements for career choice. Butler et al. (2000) tested just that, asking whether students and recruiters have good self-insight. They used two methods to estimate the preferences of students' job attributes, first, respondents were asking to rate attributes individually and second, they were asking to rate job opportunities, which grouped all attributes together, assigning a level to each attribute. Their results showed that the difference was important, as the two methods was statistically significant, indicating that students were not good judges of what attributes they find important when considering them individually. In this manner, Review of the literature of a study also answers a number of other questions. For example:

1- What research had been done on this subject before and what was the researcher's perception about the discovery of these studies?

2- What topics were present and absent in the research related to this topic?

3- What were the research questions in this study? What was not found in their previous research?

4- Which argument is more prevalent in literature? Why more common? Show this argument.

5- Who are the associate for your research? Etc.

So our research topic was job preferences of Jatiya Kabi Kazi Nazrul Islam university students. So we were performed our research by various way including identifying 10 research area and problem, methodology, sampling, data collection method (survey, interview, and questionnaire), hypothesis etc. Generally the following issues were covered under research methods, sample, data collection, hypothesis etc. Where will the research be conducted and how the study site is selected? What population will be included? Will it be a complete calculation or sample subject test? If it is a sample test, what will the sample size be and how is it determined? What sampling process will be followed to select sample units or sample responders? What were the sources of information? What methods and tools used to collect information? 


\section{Identification of Problem}

Twenty years ago, the total number of universities in Bangladesh was 26. In the space of twenty years, the number of public and private universities in the country has increased to more than one and a half hundred. Generally, with the increased of the number of universities, the number of the university's students in the country increased at a proportional rate. With the same way, the expectations of university students and their families have also increased. The highest meritorious students of the country who are studying in the university. Thus, the family and the society have high expectations of them. Students also have their own ideas about their career, and own plans. But due to various causes, it is not possible to get the expected job in this overpopulated Bangladesh. For example, the latest BCS has been attended by about five lakh where twenty-one thousand have passed naturally. But most of them had expectations of BCS. All the universities in the country have been closed for the last one and a half years due to the pandemic situation. Lots of students have committed suicide. This is the main reason for our research on university students' job expectations..... (Ahmed, 2017, academia, para. 1). 3 Millions of young people are entering the job competition every year after finishing their studies. There is a lot of talk about why young people are not getting jobs. Every year about three lac young people are joining in the job market. But the job market for young people is not growing. Research has shown that young people are demanding large sums of money as part of their expected salary. But the employers may not have allocated that amount for that position. Then no matter how well qualified the job seeker is, that's time avoid his CV.

\section{Statement of the Problem}

Pursuing a career is one of the most important events in one's life. Because, it determines a person's future, what will be his identity, status, how he'll contribute to his family as well as the society. Like every other event, there's a right time for making the decision of pursuing a career and the topmost stations of scholar life is considered as that. Scholars approach progressive education with varying pretensions, bringing wide ranges of preceding proficiency, knowledge, faculties and pretensions from secondary and more education. With the higher education scholars able to reach in their goal

UniversePG I www.universepg.com in career life. The basic structure of the study is to find out the thoughts of undergraduate students and the degree of graduation, based on their choice of future careers. It shows mainly the location of career choice. There were also efforts to identify factors that contribute to student popularity. Job expectation varies from person to person. To clarify this issue this study attempted to identify and analyze the conceding factors contributing job expectation among the students of university level and confrontation to choose their own preferences.

\section{Contextual Information}

Bangladesh is an independent sovereign state. At present time there are currently 106 private universities and 46 public universities in Bangladesh as well as there are also more colleges and national universities, so the number of students is increasing day by day. And most of the student has studied in anticipation of jobs. But there is a lot of competition on the job market. And in the context of Bangladesh, it is very difficult to get a job in line with the subject of study. Despite the increase in competition, most university students remain steadfast in their job prospects. Again, some are dreaming of becoming entrepreneurs or businessmen, however, their amount is very low..... (Ahmed, 2017, academia, para. 1). Again, some people dream of getting a good education and getting a job abroad. At this context, it can be said that number of job seekers is increasing at a huge rate compared to the vacancies in Bangladesh at present.

\section{Aims and Objectives of this study}

The main aims and objectives of this study were found out information about the job preference of the students with the present demandable job of the University student in Bangladesh. The theme of this study was - to determine the preference level of job among various students from different subjects. The research ensured the following objectives -

- Known about the present condition of Job Preference of Jatiya Kabi Kazi Nazrul Islam University.

- Found out and identified factors affecting their Job Preference.

So the aims and objectives of this research contained various issues. Such as knowing how many student are expected and want to be an entrepreneur and how many of them are going to be foreign country for a job. 


\section{Limitation of this study}

Every task has some limitations. We faced some usual constraints during the period of the data collection and preparing this article. Though we have given utmost effort to prepare this report but there were some limitations of this study. Such as follows-

- Different Format Data and lack of data related to this topic.

- Technological problem and Students personal Complexity.

- Respondents were not interested to provide exact information that we needed to know.

- As a new researcher we had lack of proper knowledge, skills, experience and materials. We tried our best.

- Our major problem was time limitation. When we conducted this research our departmental activities was so huge.

- Due to Covid Situation we cannot reached to the respondent. We send our questionnaire via online and collected data.

\section{Significance of the Study}

JKKNIU is the first 'government general university' in the Division of Mymensingh. The university was established a decade and a half ago in the name of Kazi Nazrul Islam, who is the national poet of Bangladesh. In this decade and a half, thousands of students have graduated from this university and are working in various job sectors of the country. Students of this university are in various government \& non-government organizations. With the success of senior students and the contemporary competitive job market, it was not uncommon for JKKNIU's student's job preferences to change. On the other hand, according to Job Preference, how much has been achieved in the past was also a fact. Above all, our study will make students aware of the actual job preference. They were aware of their vision and future plans. Exactly in which sector the demand is high, those interested in that sector will also be able to collectively prepare for the job. Above all, it will be possible for students to get a good idea of the job preference.

\section{Operational Definition Job Preference}

As every person is different in the earth, so their expectations are also different. This difference in everyone's expectations can be noticed for various reasons.

Career - We started getting acquainted about the word from school life. Career means a part of life. However, after graduation, getting a job means a career in our country. But getting a job does not mean just a career. Basically, his career is the subject that people are involved in as a profession outside of personal life. Simply put, a career is an important time in a person's life, which he spends as a career for his own improvement and progress.

Career and Job Preference - Naturally, in the context of Bangladesh, different perceptions are held towards university students. They can't do what they want because of an invisible social responsibility.

JKKNIU - Jatiya Kabi Kazi Nazrul Islam University is the $21^{\text {st }}$ public university in Bangladesh. The university established in 2006 at Trishal in Mymensingh. At present seven and a half thousand students are studying in twenty three departments of six faculties.

\section{Purpose of Literary Reviews}

Literature review should not just a summary of sources. Actually an annotated bibliography, instead, needed to:

* Comparative analysis among sources with other relevant literatures on the topic.

* Critical evaluation of sources.

\# Indication of contributions of different sources about the body of knowledge of the study.

* Integration of elaboration of the sources into our argument about the state of the knowledge of the topic.

\section{Importance of Literary Review}

Literary review plays an important role to complete a research by various ways. For example, understanding the whole research area, comparison between present researches and past. So there were some issues which were given below:

- It plays an important role in finding gaps by comparing any type of research with similar research which conducted in the past. And in the next study, the researcher tried to fill that gap.

- Literary review plays an important role in easily knowing what had been done and what had not been done in previous research on the subject. 
- It has very important role to contrast the various arguments, themes, methodology, controversies, expressed in the literature.

- Literary review played important role to create a new idea for performing our research.

- It's very important role to connect the literature to our own area of research and investigation.

- Provided the interpretation of existing literature in light of updated developments. In establishing the consistency in knowledge and relevancy of existing materials review of literature also crucial.

- Provided information for relevancy and coherency to check the research.

So that it also helped to find out the gist in the author's own words to sharpen the research focus, helped to comparison to show the originality and uniqueness of the research than that of the existing other researches. , helped to collect data accurately which will be appropriate for any new methodology of research than the existing ones etc.

\section{METHODOLOGY:}

Research methodology aimed to help solving problems and investigate relationship of numerous variables exist around us. Methodology is a field of the study of philosophical assumption underlying the research process, which is specific technique for data collection; it's a process of selecting, identifying and analyzing information about a topic (M. Aminuzzaman).

Methodology section of our research paper will allow readers to evaluate the overall validity and reliable, first of all methodology section usually shows the type of research we perform and how we develop our research methods. This section also described the question or problem we investigated by research. The methodology contained following elements.

\section{Sources of information}

Sources of information are very important part it influences to research strongly. Valid information makes a successful research, which outcome is better. Sources of information are classified in two types -

Primary sources: Primary data means first-hand information which collected or investigated by researcher and collected for the first time. It is basically original and has more reliability.
Secondary data: Secondary data referred to secondhand information and not originally collected rather obtained from already published or unpublished sources. Byju's (n.d.) Source of.... (Para.1). We used both primary and secondary data for our research, we collect data from face to face interviewing the students of Jatiya Kabi Kazi Nazrul Islam University and collect first hand data, We also used information from newspaper, magazine, journal etc.

\section{Sampling}

Sampling is a process which used in statistical analysis with predetermined number of observation taken from a larger population....(Chegg, n.d., Para 1). In our research we used simple random sampling method; we collected data randomly from the students of different faculties and Department. It was impossible to reach to whole population for research, so we took some students from different Department. They have involved themselves as a respondent, they answered the questionnaire and participate on the Survey, they shared their thinking feeling and basic need, we were able to know the thinking, feeling and interest of them and we also knew the job expectations of them in current situation. Investopedia (n.d.) Sampling Size ....(Para.2). We followed questionnaires and interview, and submit the questionnaire to them in online, electronic media. Both male and female students are included in our research; they gave us their valuable opinion.

\section{Sample size}

Sample size refers the number of participants or observations included in a study. This number was usually representing the whole research. The size of a sample influenced statistical properties. This was difficult to reach whole population for response; it was also impossible. Total number of respondent is ' 80 '; both male and female were our participants.

\begin{tabular}{|c|c|}
\hline Faculty & Number of respondents \\
\hline Science & 30 \\
\hline Arts and Fine Arts & 15 \\
\hline Social Science & 30 \\
\hline BBA & 20 \\
\hline Law & 5 \\
\hline
\end{tabular}

\section{Data Collection Method}

Data collection method describe what have we done, how have we done, and how we have collect organized data to the research. Data collection methods are -1). 
Interview; 2). Questionnaire and Survey; and 3). Documents. We used interview, questionnaire and survey method for data collection. We select our target people and taking face to face interview and submitted them questionnaire and survey, it contains open ended or closing question and explanation. They have responded easily and involved themselves in our research, which made our research stronger. Data collection classified into two broad categories: 1). Primary data collection and; 2). Secondary data collection.

Primary Data Collection - Primary data collection by definition was the gathering of raw data from different sources. It was a process of collecting the original data by a researcher for a specific research purpose. It could be further analyzed into two segments: 1). Qualitative data collection method and 2). Quantitative data collection methods.

Secondary data Collection - Which is not original, already someone created these data that means second hand data. We used qualitative and quantitative data in our research, students expressed their experience thoughts and opinions in questionnaire and survey programme, they also expressed their thought by quantifying opinions and behavior.

\section{Data analysis}

Data Analysis is the process of application of different software by statistical technique. Statistics \& Applied Economics Consulting (n.d.) Data Analysis.... (Para. 1). For analysis I used MS Word, MS Excel and different kind of software. To get different chart and percentage -

\section{$\%=\mathbf{n} / \mathbf{m} \times 100$}

Where, $\mathrm{m}=$ number of respondents and $\mathrm{n}=$ total number of respondents.

Data analysis contains two segments; Qualitative Analysis - This approach mainly answers questions such as 'why,' 'what' or 'how.' Each of these questions was addressed via quantitative techniques such as questionnaires, attitude scaling, standard outcomes, and more. Such analysis was usually in the form of texts and narratives, which might also include audio and video representations. Quantitative Analysis - Generally, this analysis measured in terms of numbers. The data here present themselves in terms of measurement scales and extend themselves for more statistical manipulation.

UniversePG I www.universepg.com

\section{Descriptive Analysis}

Descriptive analysis shows a statistical picture of a whole data which is helpful for analysis and final outcome. It summarizes and categorizes the response. The conversion of raw data into a form that will make it easy to understand \& interpret, i.e., rearranging, ordering, and manipulating data to provide insightful information about the provided data. Descriptive statistics summarized or described the characteristics of a data set. Descriptive statistics consists of two basic categories of measures: measures of central tendency and measures of variability (or spread). (investopedia). It showed us a percentage of student's demand, we separated students those who were want to join government job, and we also separated those students who were wanted to private firm, corporate job. Those who were interested to BCS, government job, we studied their lifestyle, growing up, financial status, we find out that Majority were from middle class and they had fascination for BCS or government service. They wanted to fulfill their goal by joining in government service. Those who were urban centric maximum are interested to corporate job, private firm (Sami et al., 2021).

\section{Hypothesis}

There was some hypothesis which followed from the objectives needed to be tested.

* Teachers of different departments influence Job preference of their students.

* Transparency in recruitment process affects students Job preference.

\section{ANALYSIS AND FINDINGS:}

In this fourth chapter mainly focused to present data collected from the field through various methods and analyzes these data with the research questions. Main objectives of the study find out answers to the research questions. This chapter will attempt to consider Job Preferences of JKKNIU students and find out the influencing factors related job. In this part we also discussed about male and female students choice of their career. Answers of the questions of research in this chapter had been presented by Pie, Chart, Bar, Column and table as descriptive methods.

\section{Demographic Analysis}

In below, the demographic data are presented by chart and diagram- 


\section{Gender of Respondent}

The Fig 1 illustrated that the survey was conducted among respondent from both male and female students. The data has been collected from 80 students, of them $33(41.25 \%)$ respondent are female students, 47 (58. $75 \%)$ respondent are male students. The respondents of male and female are not equal. The male respondent's percentage is higher than female respondents.

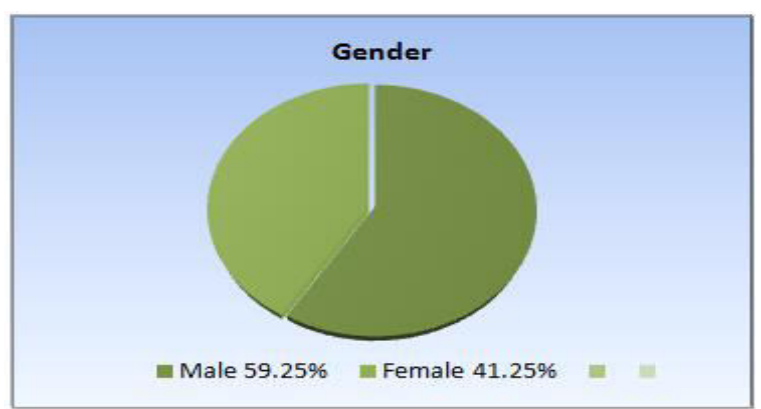

Fig 1: presents the percentage of gender distribution of sample.

\section{Gender of respondents according to their academic faculties}

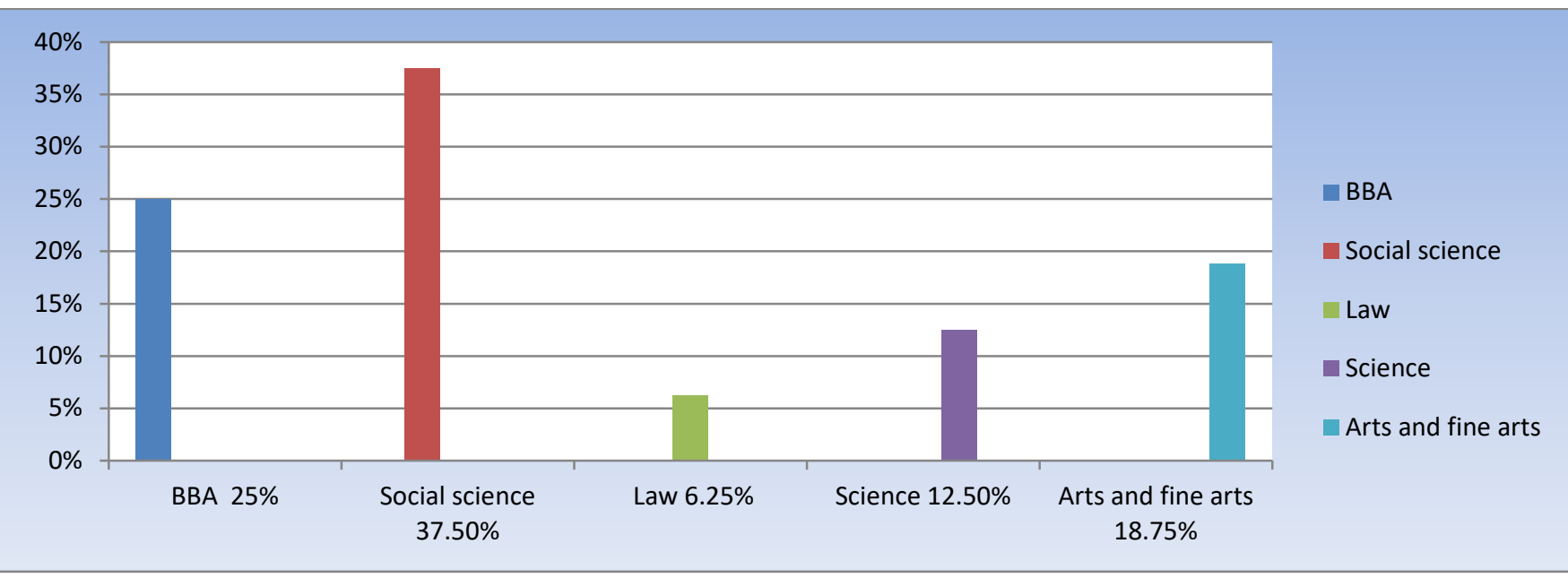

Fig 2: Presents the percentage of academic faculties by respondents.

The Fig 2 illustrated that this survey was conducted among respondents from different academic faculties of Jatiya Kabi Kazi Nazrul Islam University. The data has been collected from 80 students and (definite percenttage among the total) students were taken from each of the five faculties - Arts, Science, Law, Social Science, BBA faculty. Among the 80 student's $18.75 \%$ respondents were Arts faculty, $12.05 \%$ respondent from Science faculty, $6.25 \%$ respondents from Law faculty, $37.05 \%$ respondents from Social Science and 25\% respondents from BBA faculty.

The Fig 3 illustrated that this survey was conducted among respondents from different academic years. The data has been collected from 80 students, of them 10 $(12.05 \%)$ respondents are $1^{\text {st }}$ year students, 15 (18. $75 \%)$ respondents. $2^{\text {nd }}$ year Students, $22(27.05 \%)$ respondents are $3^{\text {rd }}$ year students, $24(30 \%)$ respondents are $4^{\text {th }}$ year students and rest of the $9(11.25 \%)$ respondents are masters or above level students. The entire student from these all groups are mostly tried to take as respondents.

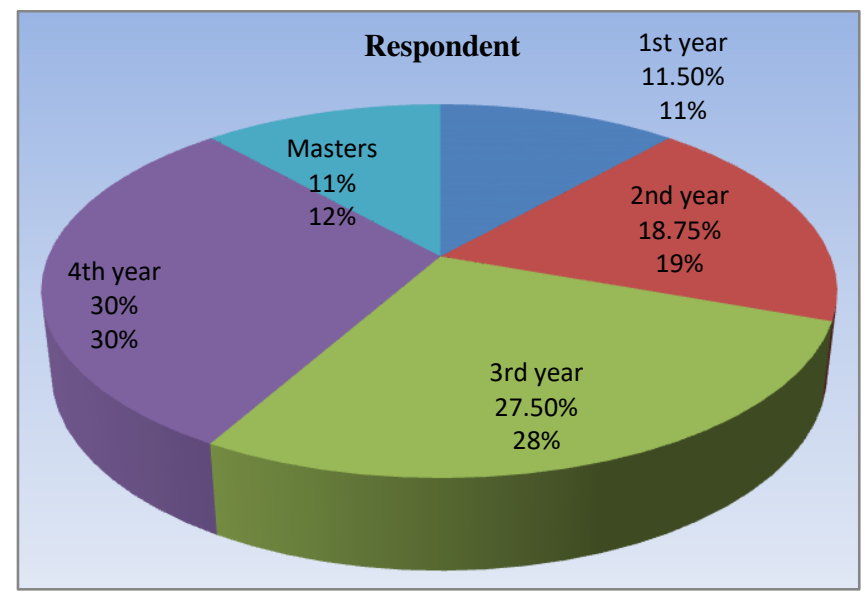

Fig 3: Presents the percentage of academic years of the respondents.

\section{Academic year of Respondent}

All the respondents from different faculties are asked this question - Do you want to do job? The answer of that question presented in above by diagram. The data 
has been collected from all faculties respondents, of them $85 \%$ of respondents are chosen answer "Yes" and rest of the $15 \%$ respondents are chosen "No". They would rather prefer entrepreneurship than Job. All the respondent were asked to rank their Expectation of career in 1-4 (Where 1 is the most preferable) form a list of career choices such as - BCS/1st Class Job, Private Job, Others Govt. Job, and Bank Job. The data of this ranking were processed from different dimension; Data of male respondents, Data of Female respondents, Data of Five different faculties and data of different academic year (Pathiranage, 2021).

\section{Career/Job Preference}

There 80 students from different faculties and different academic years were asked to rank their Job preference from a list of four different career choices.
The data of their ranking has been presented below using a diagram

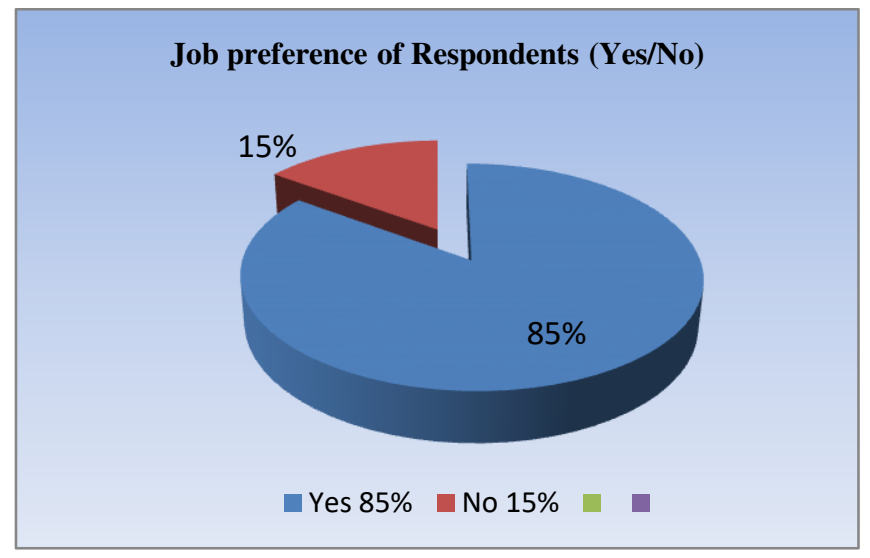

Fig 4: Percentage of respondents Job Preference.

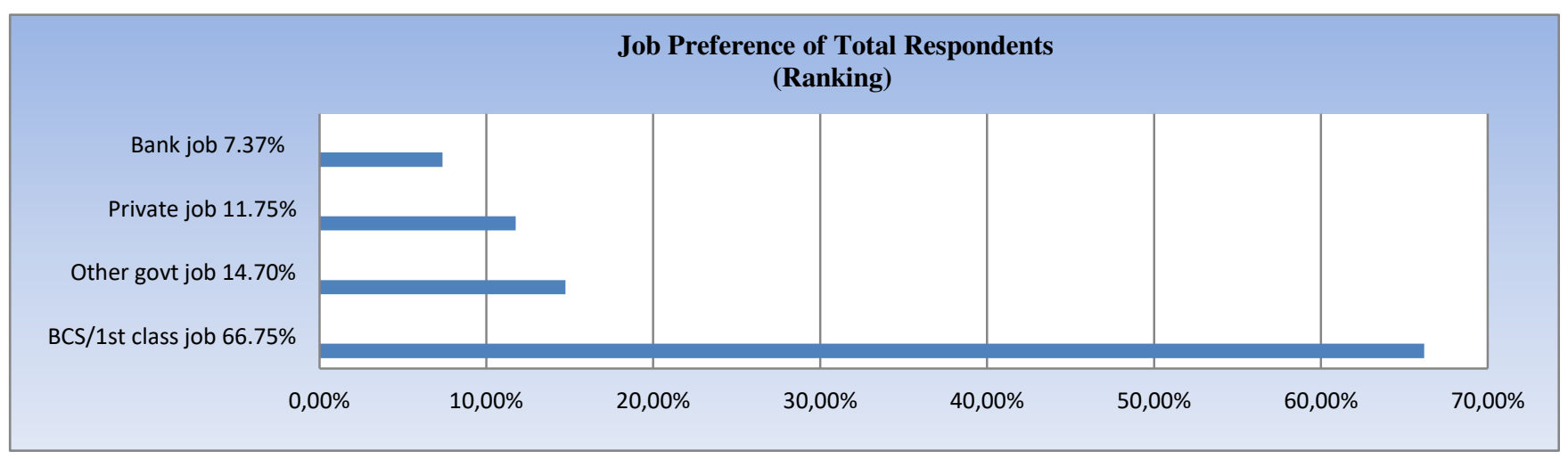

Fig 5: Ranking of Career by Total Respondents.

\begin{tabular}{|c|c|c|c|c|}
\hline SL & BCS/ $/ \mathbf{1}^{\text {st }}$ class & Other govt job & Private job & Bank job \\
\hline $4^{\text {th }}$ rank & & & & $7.37 \%$ \\
\hline $3^{\text {rd }}$ rank & & & $11.75 \%$ & \\
\hline $2^{\text {nd }}$ rank & & $14.70 \%$ & & \\
\hline $1^{\text {st }}$ rank & $66.75 \%$ & & & \\
\hline
\end{tabular}

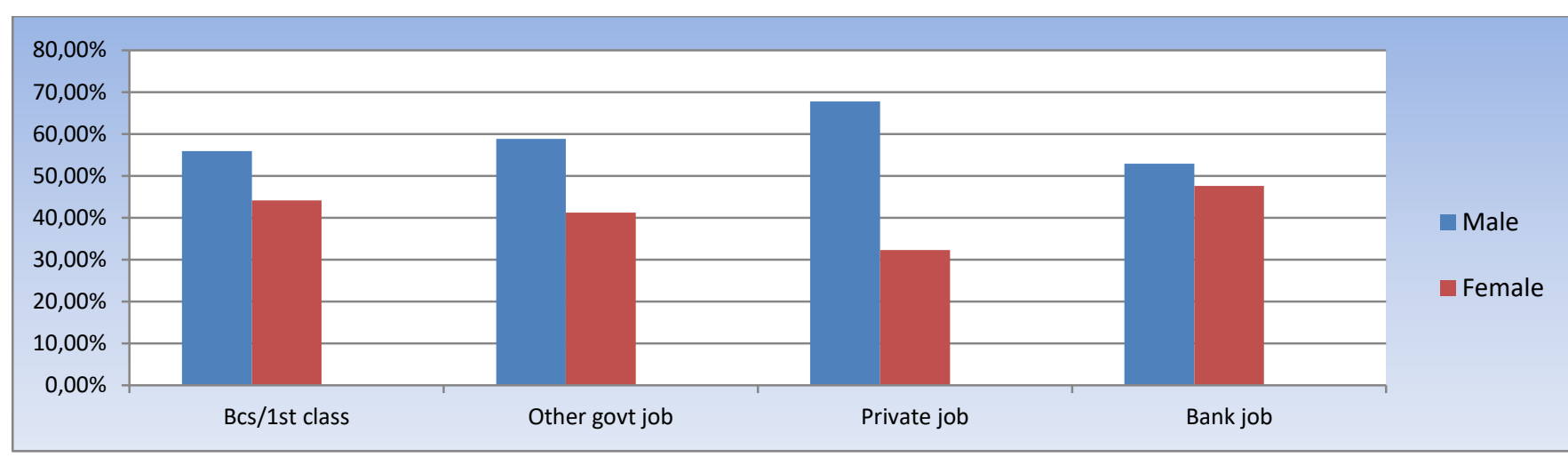

Fig 6: Ranking of career by male female students.

\begin{tabular}{|c|c|c|c|c|}
\hline SL & BCS/ $^{\text {st }}$ class & Other govt job & Private job & Bank job \\
\hline Male & $55.88 \%$ & $58.82 \%$ & $67.75 \%$ & $52.94 \%$ \\
\hline Female & $44.12 \%$ & $41.18 \%$ & $32.25 \%$ & $47.60 \%$ \\
\hline
\end{tabular}


From the Fig $\mathbf{5}$ it can be seen that most of the respondents $66.18 \%$ rank BCS as their first choice. Here, $2^{\text {nd }}$ choice is Other Govt. job which percentage is $14.70 \%, 3^{\text {rd }}$ choice is Private Job which percentage is $11.75 \%, 4^{\text {th }}$ choice is Bank Job which percentage is $7.37 \%$ on the basis of this ranking of respondents.

From the Fig 6 it illustrated that the respondents (male) $55.88 \%$ and (female) $44.12 \%$ rank BCS as their career choice. The respondents (male) 58.82\% and (female) $41.18 \%$ rank Other Govt. job as their career choice. On the other hand, Bank as a career choice percentage of male respondents is $52.94 \%$ and female respondent is $47.06 \%$. And the last private job as a career choice percentage of male respondents is $67.75 \%$ and female respondents are $32.25 \%$.
From the Fig 7, it founded that most of the respondent (26.25\%) give more emphasize on the 'status' as reason for choice than others in making Job preferences. The 2nd reasons for choice their career was job security which percentage was (23.75\%). $25.25 \%$ of respondents cite financial benefits as the third most important factor in their career choices. Respondents noted the importance of other benefits and allowance benefits which are $15 \%$ and $7.50 \%$ respectively. As can be seen from the above analysis, most of the respondent had given priority to social status in terms of career choice. It was clearly seen that, most of the respondents (26. $25 \%$ ) said that there was an influence of their social status in their Job preferences. So, we decided from this finding that, social status was a very significant factor in choosing a career.

\section{Some specific personal issues of a person that effect the decision of his/her career choice}

\section{Reasons of Choice}

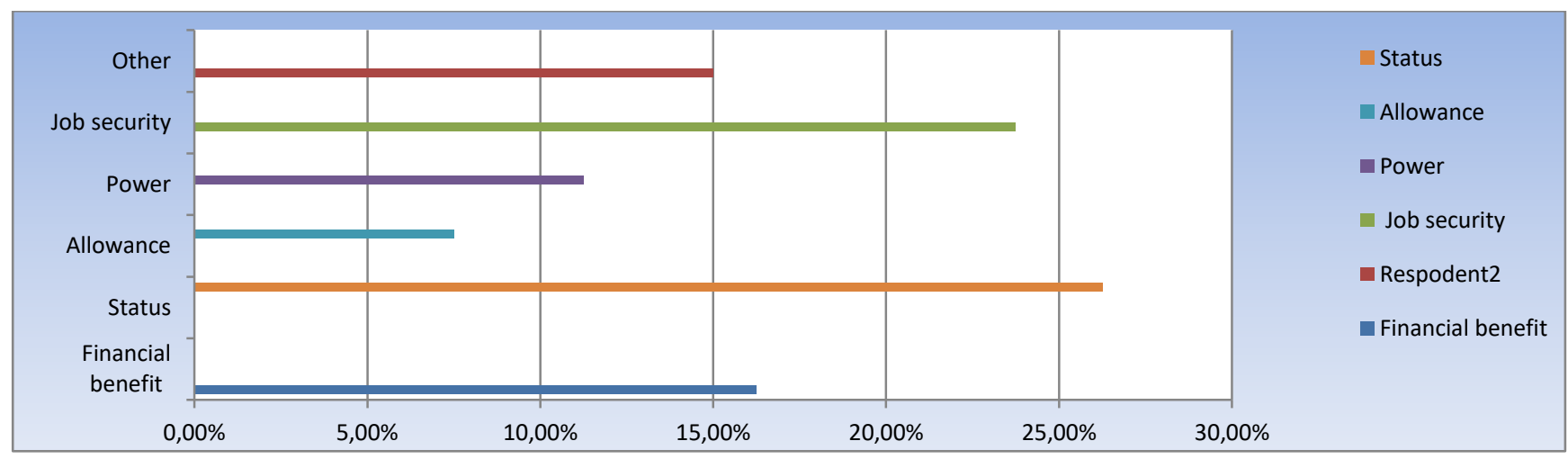

Fig 7: Ranking of influenced of different job attributes in Job preference.

\begin{tabular}{|c|c|c|c|c|c|c|}
\hline SL & Financial benefit & Status & Allowance & Power & Job security & Other \\
\hline Respondent & $16.25 \%$ & $26.25 \%$ & $7.50 \%$ & $11.25 \%$ & $23.75 \%$ & $15 \%$ \\
\hline
\end{tabular}

\section{Ranking}

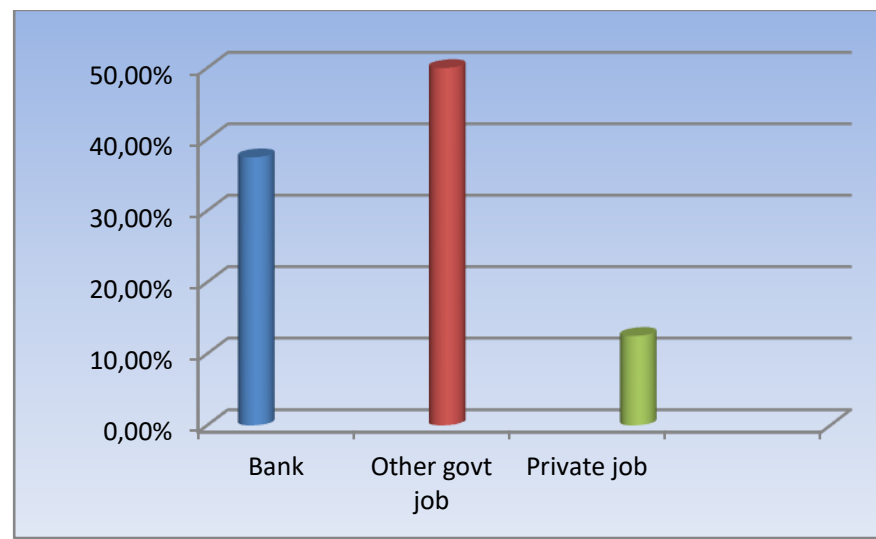

Fig 8: Ranking of others job (except $1^{\text {st }}$ choice) by Total Respondents.

\begin{tabular}{|c|c|}
\hline SL & Respondents \\
\hline Bank & $37.50 \%$ \\
\hline Other Govt job & $50 \%$ \\
\hline Private job & $12.50 \%$ \\
\hline
\end{tabular}

From the Fig 8 it can be seen that most of the respondent $50 \%$ rank other government job as their preference. Here, 2nd choice was Bank job which percentage is $37.50 \%$, and 3rd choice was Private Job which percentage is $12.50 \%$, on the basis of the ranking of respondents. The above analysis was based on the Respondents jobs other than their first choice because the first choice of the respondents was BCS or first class job which percentage was 66.18 percent. 
The Issues relevant with respective departments of respondents which have impact on the decision of Job preferences

In our analysis of the previous section, we noticed that there was a significant difference between the preferences of students from different fields. It can be understood that some of the causes are within their departments. In these cases, 'to assess the impact of the problems associated with the relevant respondent departments, a survey and discussion was conducted on the following issues.

Does the department's study apply to the job market? Does a different departmental teacher give any kind of advice about Job's interests/career, if so - what is it? We have got respondents from different departments from these five faculties. These departments are given in the following with their respective faculty name

\section{Faculty of Arts}

Bangla language and literature, Theatre and performance studies, English language and Literature, Music, Film and media, Philosophy.

\section{Faculty of Fine Arts}

Fine Arts.

\section{Faculty of Science and Engineering}

Computer Science and engineering, Electrical and Electronic Engineering, Environmental Science and Engineering, Statistics.

\section{Faculty of Social Science}

Economics, Public Administration and Governance Studies, Folklore, Anthropology, Population Science, Local Governance and Urban Development, Sociology.

\section{Faculty of Law}

Law and Justice

\section{Faculty of Business Administration}

Accounting and information systems, Finance and banking, Human resource management, Management.

Does the course curriculum relevant with the job market? To know the thought about their course curriculum in relation with the job market, 3 answer/options were given as answer. These options were - 1). Yes; 2). No; Course curriculum did not need to be relevant with job market. Yes 50\%, No $33.33 \%$ and course curri- culums doesn't need to be Relevant with job Market $16.67 \%$ (Fig 9).

\section{Relevancy of Departmental Courses with Job Mar- ket (Social Science)}

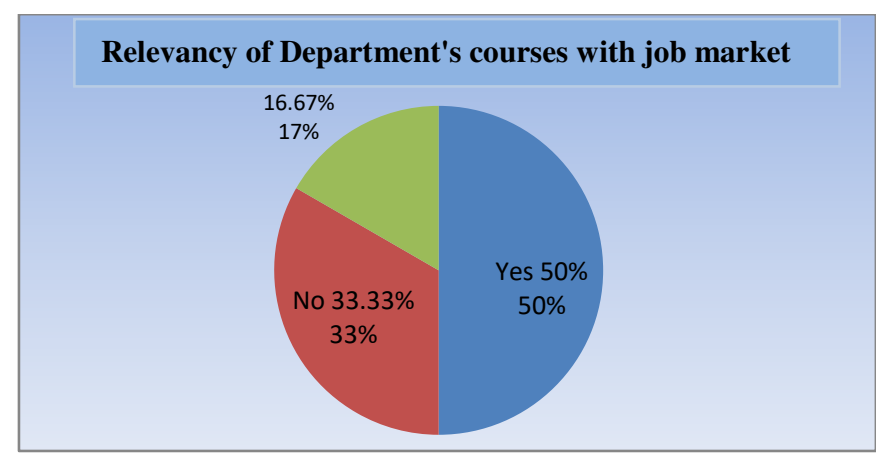

Fig 9: Perception of the total respondent about relevancy of Department's courses with job market.

Yes $53.35 \%$, No $40.00 \%$, and Course curriculum doesn't need to be relevant with job Market $6.67 \%$ (Fig 10).

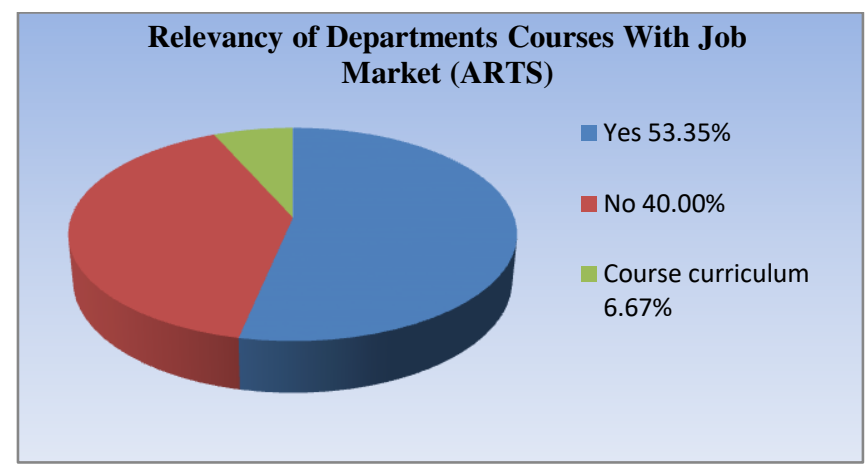

Fig 10: Perception of the 'Arts Faculty' respondent about relevancy of Department's courses with job Market.

Yes 50\%, No 30\%, and Course curriculum doesn't need to be relevant with job market (Fig 11).

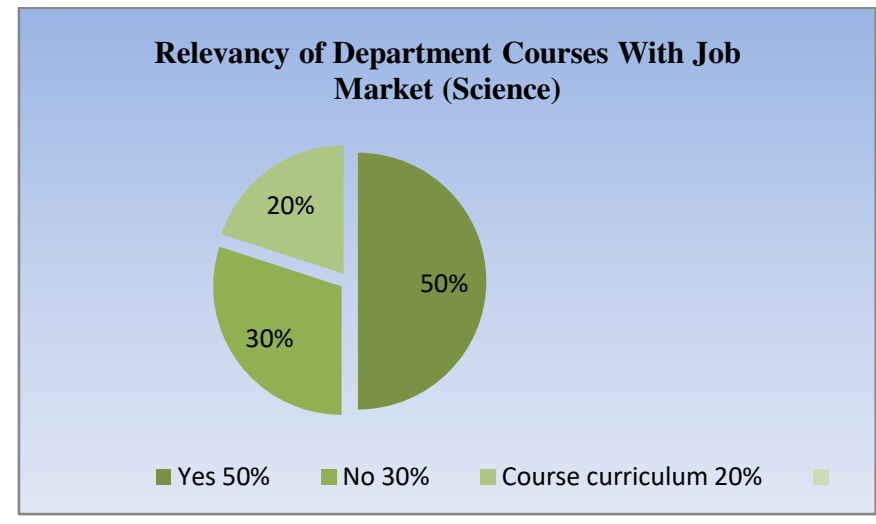

Fig 11: Perception of the 'Science faculty' respondent about relevancy of Department's courses with job market. 
Yes $60 \%$, No 40\%, and course curriculum doesn't need to be relevant with job market (Fig 12).

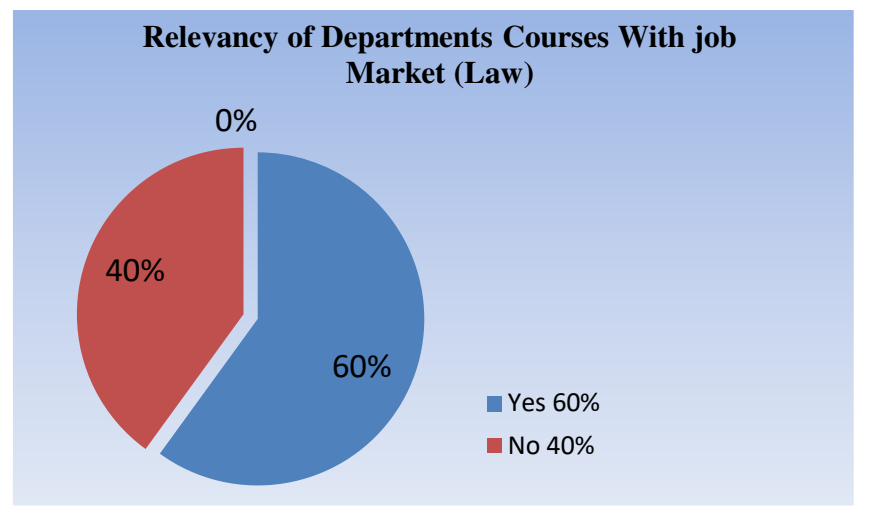

Fig 12: 'Law faculty' respondent about relevancy of Department's courses with job market.

Yes 50\%, No 33\%, and course curriculum doesn't need to be relevant with job market 17\% (Fig 13).

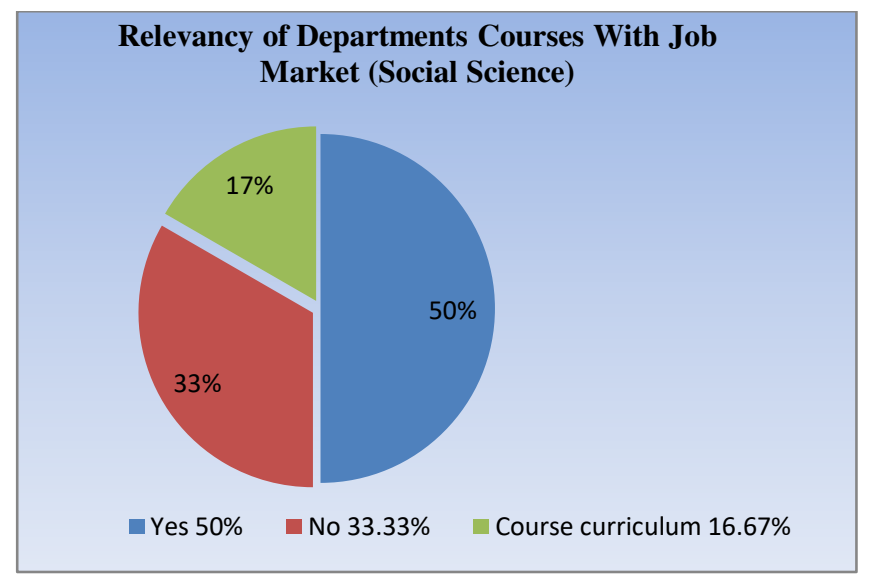

Fig 13: Perception of the 'Social science faculty' respondent about relevancy of department's courses with job market.

Yes $50 \%$, No $30 \%$, and course curriculum doesn't need to be relevant with job market 20\% (Fig 14).

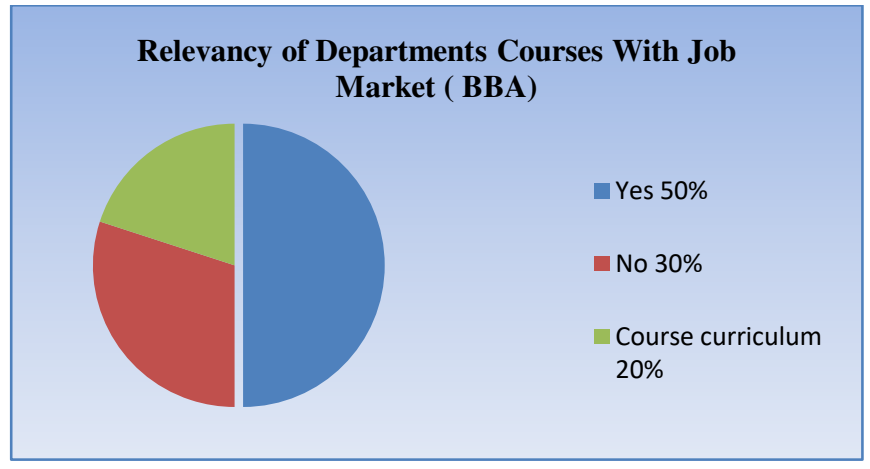

Fig 14: 'Business Administration (BBA) faculty' respondent about relevancy of Department's courses with job market.

\section{Analysis of the figure total respondents}

From the Fig 9 it was seen that, total respondent actually $42.30 \% \%$ think that the department's course curriculum relevant with the job market. On the other hand, $36.50 \%$ of the respondent said that course curriculum was not relevant with job market. A few respondents actually $21.20 \%$ think that Course Curriculum doesn't need to relevant with job market. So, it can be said from above discussion that - as nearly about half of the respondent said that department's Course Curriculum was relevant with job market, so it can be said that a significant number of department of Jatiya Kabi Kazi Nazrul Islam University conduct course curriculum relevant with job market.

Comparative analysis among all faculties' respondents in below:

Looking at the above analysis, we can see that the respondents of the faculty of arts said that their course was relevant with job market as answer yes and which percentage was $53.33 \%$ and some respondents said no which percentage was $40 \%$. The rest of the respondents said that it was not necessary to relevant job curriculum with job market which percentage was 6.67 . The respondents of science faculty said yes to the answer that their course was relevant with job market which percentage is $50 \%$ and some respondents said no which percentage is $30 \%$. The rest of the respondents said that it was not necessary to relevant job curriculum with job market which percentage is $20 \%$. The respondents of social science faculty said yes to the answer that their course is relevant with job market which percentage is $50 \%$ and some respondents said no which percentage is 33.33 percent. The rest of the respondents said that it was not necessary to relevant job curriculum with job market which percentage is $16.67 \%$. Finally, the respondents of BBA faculty said that their course is relevant with job market as answer yes and which percenttage are $50 \%$ and some respondents said no which percentage is $30 \%$. The rest of the respondents said that it is not necessary to relevant job curriculum with job market which percentage is $20 \%$.

Influence of relevant departmental teachers in favor of students:

To assess the impact of teachers on different student departments, all respondents from different faculties were asked these questions - 'Does a different depart- 
mental teacher offer any kind of advice about Job's interests / profession, if so - what are they?' The answer

to this question is presented in the following diagram.

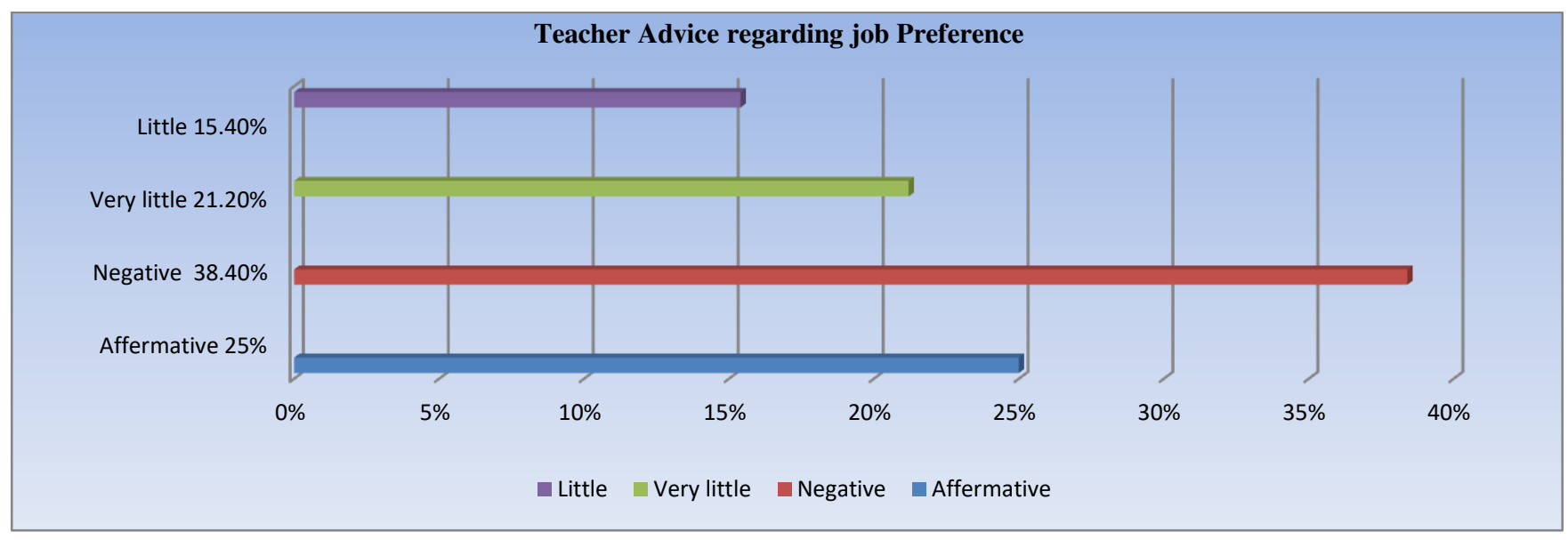

Fig 15: Teacher's influence/Advice regarding job.

Analysis of the data for Total Respondent: From the Fig 15 it can be seen that, 25\% of total respondent give affirmative answer where $38.4 \%$ of total respondent give negative answer of the question and $21.2 \%$ respondent marked very little option and another $15.4 \%$ respondent marked little. From this analysis it is understood that teachers give them job related advice with a percentage of about $20.5 \%$.

However, the respondents replied that most of the faculty and department teachers did not give much job related advice. In some cases, teachers have given very little advice. Respondents were asked "do you involved in part time job"? The answers were collected through "YES" and "NO". It was found that $62.50 \%$ of respondents said that they were involved in part time job and it turned out that more than half of the res- pondents here answered "yes." The rest of the respondents said that they were not involved in part time job and the percentage is $37.50 \%$. They answered No and the number of respondent was less than half.

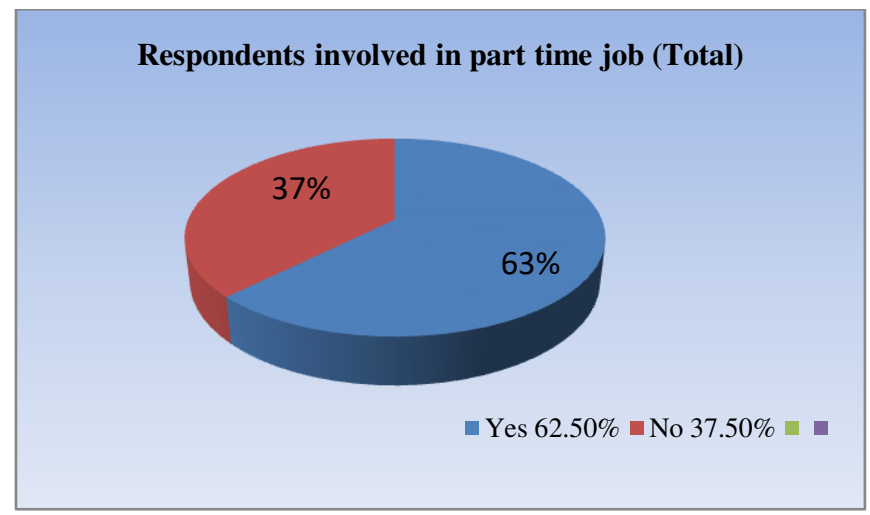

Fig 16: Percentage of respondents involve in part time job.

\section{Part time job help to get expected job}

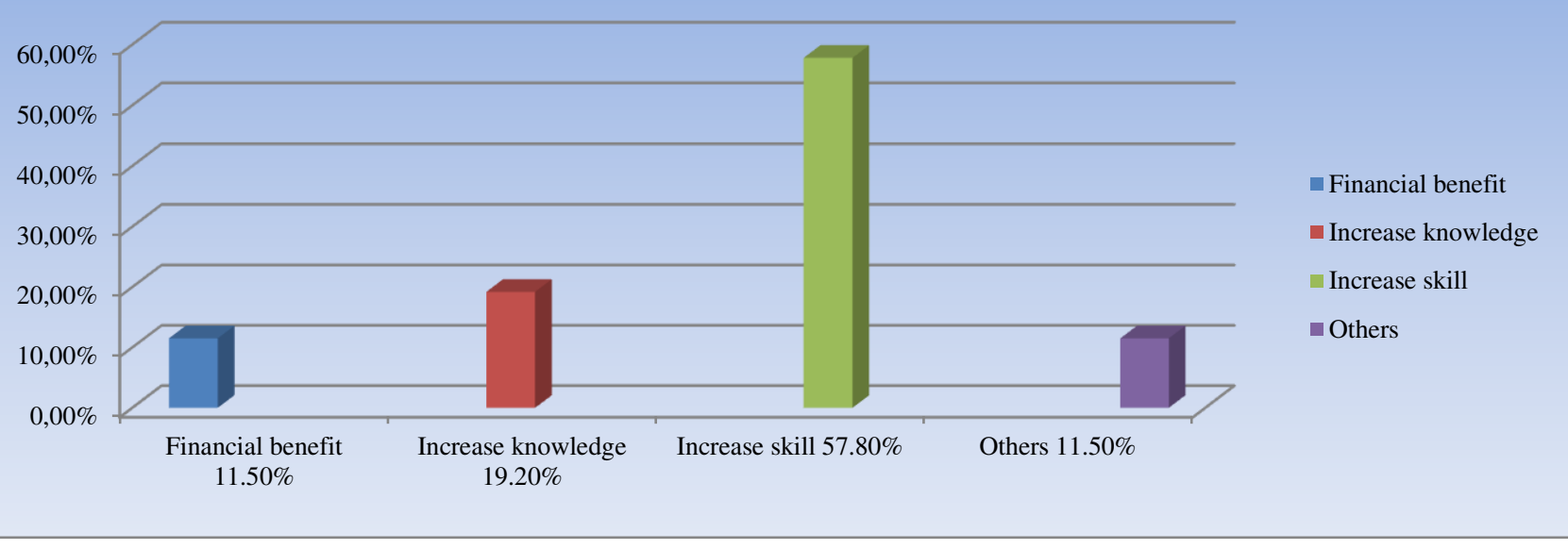

Fig 17: Illustrated about the way part-time jobs help to get better jobs. 
Respondents were asked, "How do you think a parttime job will help you get a job"? All the respondents have tried to answer this question in different ways. Some of them said that part time job helps in their skill development which will help them get a job later they think. More than half, about 57.80 percent of respondents think that part-time job helps their skill development and this skill will help them to get their expected job. Some of them said that part time job will help them to increase their knowledge and they think that knowledge will help them to get good job. The second highest 19.20 percent think part-time jobs help them increase knowledge and by applying developed knowledge they will get their expected job. Many of them think that part time job will help them financially and will increase their knowledge and skill development and the percentage is $11.50 \%$. Answer had also been received from respondents whose were benefited from the part -time jobs financially. The rest of the respondents think that part-time jobs will help them in others ways, which is $11.50 \%$. Impact of the descriptive level of the personalized employment process: $11.50 \%$ $19.20 \% 57.80 \% \quad 11.50 \%$ and $0.00 \% \quad 10.00 \% \quad 20.00 \%$ $30.00 \% \quad 40.00 \% \quad 50.00 \% \quad 60.00 \% \quad 70.00 \%$. Financial Benefit Increase Knowledge Increase Skill Others. Part time job will help to get expected job. To find out if there was a descriptive influence over the level of personalized hiring process; respondents were asked the question 'Do you like a job that does not have a transparent hiring process? Among the respondents who said yes to this question were asked to explain the reason for their position.

\section{Collected responses delivered to the following using a pie chart}

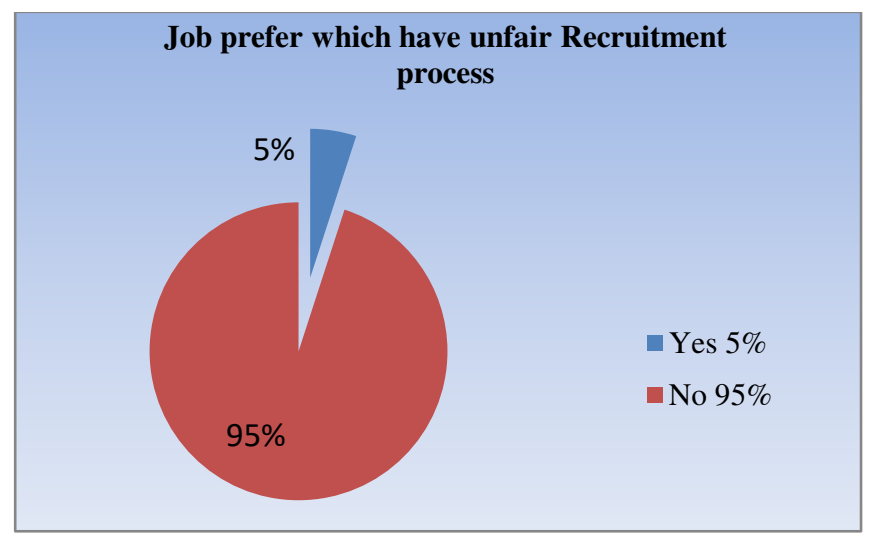

Fig 18: Preferring job which have opaque recruitment process.
Data and information analysis: From the above Fig 18, it illustrated that, the majority of respondents (95\%) responded negatively to choosing a career with an opaque recruitment process. This kind of result was expected by us and this was because people have habited of answering the question thus how good you look to other people, in short - you give the usual answers. Unfortunately, if there was anyone in this negatively charged group who can pursue a job despite having an invisible recruitment process they will not be visible due to the tendency of 'Normative Answering'. However, we found other respondents who had the courage to state their position on the question, and $5 \%$ of the total respondent responding positively. $5 \%$ No, $95 \%$ Job prefer which have unfair recruitment process. Those respondents said yes they mentions their logic to this answer respondents commented that ' $100 \%$ transparency is not possible'.

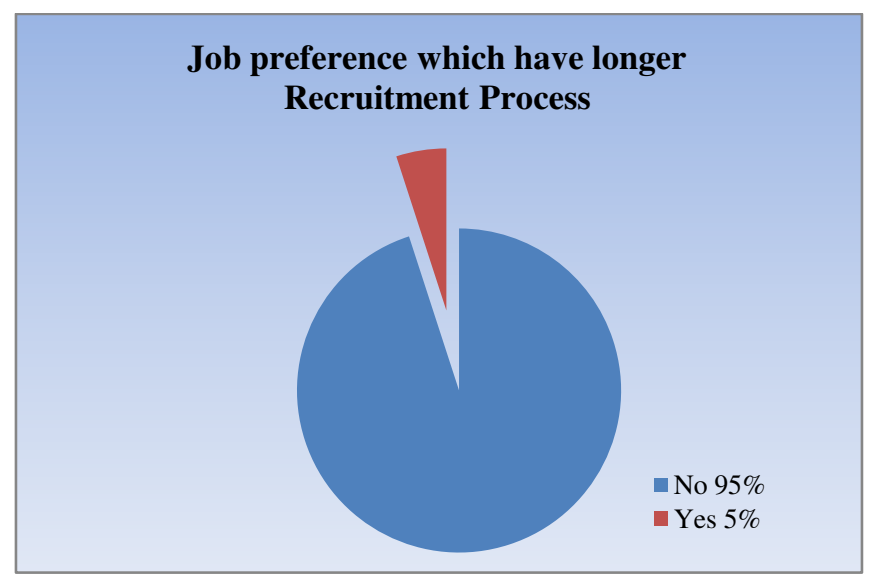

Fig 19: Preferring job which have longer recruitment procedure.

All respondent of JKKNI University were asked would you prepare a job that has long process. All the respondents have tried to answer this question and their answer have been analyzed and shown in the figure below. In Fig 19, the respondents answer is analyzed by option "Yes" and "No." Most of the respondents chose no answer from this option to answer this question. Their opinions are explained with the help of diagram and which percentage is $95 \%$. The rest of $5 \%$ respondents said that although the recruitment process in long, they are interested in getting job. Analysis of the final discussion above showed that most students were less interested in longer recruitment process job. 


\section{Factors influence respondents to pursuing Career (Multi Choice)}

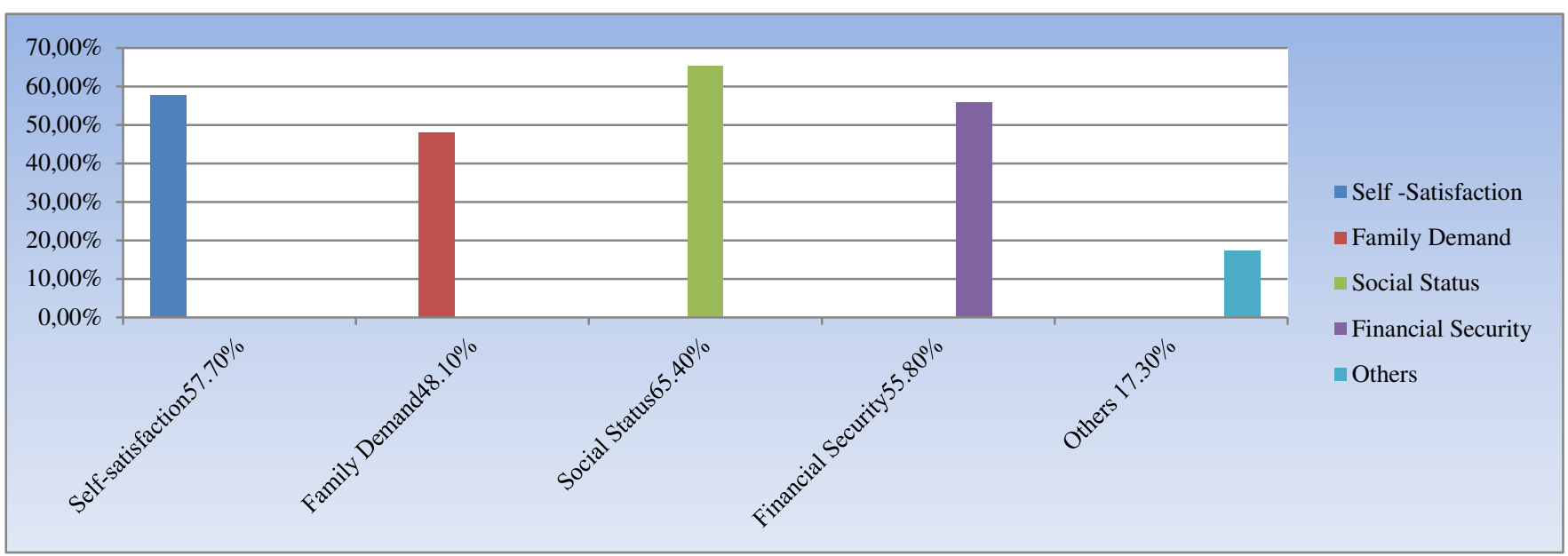

Fig 20: Factors influenced respondents to pursuing Career (Multi Choice).

From the Fig 20, it illustrated that most of the respondent $(65.40 \%)$ give more emphasize on the 'social statuses as reason for choice than others in case of Job preferences. The $2^{\text {nd }}$ factor influenced their career was self-satisfaction which percentage is $(57.70 \%)$. $55.80 \%$ of respondents financial benefits as the third most important factors that influenced their career choices. Respondents noted the family demand was one of the most important factors that influence their career choice which percentage is $48.10 \%$. Rest of the respondent mentions others factors that influenced their career choice which percentage were $17.30 \%$.

As can be seen from the above analysis, most of the respondents have given priority to social status in terms of career choice. It is clearly seen that, most of the respondents $(65.40 \%)$ said that there was an influence of their social status in their Job preferences. So, we decided from this finding is that, social status was a very significant factor in influencing of one's career.

The Issues relevant with personal opinion of respondents which have impact on the decision of Job preferences: All respondents were asked the question how different organization of Jatiya Kabi Kazi Nazrul Islam Uni-versity help students to get the job they want. All res-pondent were asked for their views on this question and their views are highlighted as follow -

JKKNIU-Debating Society; some respondents said that the debating Society of JKKNIU helps them in soft skill development and critical thinking. It will help them to communicate easily to other competitor and it will also help to be a good leader and will increase the English Speaking fluently.

JKKNIU Skill Development Club; some of the respondent mentioned that the Skill development club of JKKNIU helps them in soft skill development with motivation. They arranged different meeting, seminar and program to motivate and develop the student's creativity and knowledge that will help them in future. It also playing a great role to improve different skill. Many of the respondent from different departments said that the club do not Support them very much, but they do help to increase morale and be a good person. These organization helped the students various job related information and these organization working in mind satisfaction and refreshment through the various exercise in which for getting help in the particular job.

The response of the respondents were in the below-

\begin{tabular}{|c|c|}
\hline $\begin{array}{c}\text { Reason of Choice Job rather } \\
\text { than entrepreneurship }\end{array}$ & $\begin{array}{c}\text { Percentage of } \\
\text { respondents }\end{array}$ \\
\hline Lack of Capital & $15 \%$ \\
\hline Lack of Security & $18 \%$ \\
\hline Demand of family & $7.5 \%$ \\
\hline Power Practice & $2.5 \%$ \\
\hline From Fascination & $3 \%$ \\
\hline Not Interested & $6 \%$ \\
\hline $\begin{array}{c}\text { Lack of Morale, courage, desire, } \\
\text { time and coordination }\end{array}$ & $16 \%$ \\
\hline Lack of Government policies & $10 \%$ \\
\hline For social value and status & $22 \%$ \\
\hline
\end{tabular}

Personal opinion of respondents of choosing the Job rather than entrepreneurship - 
All respondents were asked in recent times, a large number of university students are trying to become entrepreneurs without getting a job. Why are you going to Job without being an entrepreneurship?

\section{Test of hypothesis}

$\mathbf{1}^{\text {st }}$ hypothesis - Teachers from different departments influence Job preference of their students. From my research results we can see that teachers from different departments influenced students in their career choice. While the level of influence is not very high, teachers generally influence students in their career choice.

$\mathbf{2}^{\text {nd }}$ hypothesis - It can be seen that, the majority of respondents $(95 \%)$ responded negatively to choosing a career with an opaque recruitment process.

\section{Summary of the Findings}

Job Preference - The finding of the of these research paper highlighted the most preferable job of Jatiya Kabi Kazi Nazrul Islam University students is "Bangladesh Civil Service (BCS)" job. In this job male and female students were both highly interested. Most of the student prefer this job because it's provides Power, Money, more security and so on.

The second most preferable job by Jatiya Kabi Kazi Nazrul Islam University students is "Other Government Job". They choose government job because this is more secured than other job. The Third most preferable job by Jatiya Kabi Kazi Nazrul Islam University students is "Private Job" and "Bank Job" respectively. Because it's provides smart salary, loan and other facilities.

\section{Factors that affects Job preference}

The study of this research shows that the influential factor in job preference by the respondent $(65.40 \%)$ is 'social statuses. This factor is the highest rank by the total respondents. The $2^{\text {nd }}$ factor influence their career is self-satisfaction which percentage is $(57.70 \%)$. The third most important factor that influenced their career choices is financial benefits which percentage is $55.80 \%$ by the rank of respondents. Respondents noted the family demand is one of the most important factors that influence their career choice which percentage is $48.10 \%$. This was the fourth important factor which influenced their job choice.

\section{Suggestions for policy implications}

The following recommendations are made on the basis of the findings of the study -

i) Both male and female students have a strong desire to complete education at a due time. So if the authority takes proper steps to overcome the lengthy process in semester system, it will be helpful for the students and they will get huge time to prepare themselves for competitive job exam.

ii) Educational awareness and family support should also rise for increasing the confidence level of the students that they are the wealth of the nation. And without hardworking, it will not possible to shine in life.

\section{CONCLUSION:}

In this research, an attempt has been made to highlight the job prospects of the students of the Jatiya Kabi Kazi Nazrul Islam University. Because of Corona situation, the data of this research had been collected by online. Total of 80 people participated in the research. In this research, samples had been taken from every department of the university. Where students from first year to postgraduate have participated. Where $75 \%$ male and $25 \%$ female students participated. According to this research, most of the student here are expecting 1st class jobs. The reason for this was that they have given priority to job status, security and allowances. Fortytwo percent of university students think that Departmental study will help them get a job. 36\% think reading the department will not help them get a job. How do the teachers of the department cooperate in the job? Mixed opinions were found in response to such questions. They also said that the working clubs/organizations of the university help in getting the desired job. The students here are not interested in jobs that are not transparent.

\section{ACKNOWLEDGEMENT:}

At first I would like to pay my thanks to Almighty Allah, for helping me to do all the works with perfection. I am really grateful because I managed to complete my research within the time when it was so difficult for me. This work cannot be accomplished without the efforts and cooperation of my students. There were a lot of articles that helped me by providing valuable information, advice and guidance for the completion of this Research Paper in the long time. I also sincerely 
thank to my teacher, Head of the economics Dept., Professor Dr. Nazrul Islam for helping me by providing knowledge of advanced research and for the guidance and encouragement to finish this article. Finally, I would like to express my gratitude to my friends and respondents for the support and willingness to spend some time with me to fill in the questionnaires.

\section{CONFLICTS OF INTEREST:}

No conflict of interest at the author ends

\section{REFERENCES:}

1) Anana, E. Nique, W. (2010). Personal values in relation to graduate career choices, International Journal of Public Sector Management, 23(2), 158168. https://doi.org/10.1108/09513551011022500

2) Bojuwoye, O., Mbanjwa, S. (2006). Factors impacting on career choices of Technikon students from previously disadvantaged high schools. Journal of Psychology in Africa, 1, 3-16. https://doi.org/10.1080/14330237.2006.10820099

3) Carpenter, P., \& Foster, B. (1977). The career decisions of students teachers. Educational Research and Perspectives, 4(1), 23-33. https://datasara.com/secure4dl/papersMag/DS15049f2ozvw6av5wqx4w8zid2qig730.pdf

4) Deaconu, A., Radu, C. and Ramos, MC. (2013). Students' Perception on Career in Romania and Portugal - a Comparative Analysis, Review of International Comparative Management. 14(1), 5-13.

5) Felton, S., N. Buhr, and M. Northey. 1995. "Factors influencing the business student's choice of a career in chartered accountancy." Issues in Accounting Education (spring), 131-141. https://www.sciencedirect.com/science/article/abs/pii /0748575194000271

6) Ferreira, I., Wendel-Vos, W., Kremers, S., van Lenthe, F.J. and Brug, J. (2007). Environmental correlates of physical activity in youth-a review and update. Obes Rev. 8(2):129-54.
https://doi.org/10.1111/j.1467-789X.2006.00264.x

7) Ghuangpeng, Siriwan (2011). Factors influencing career decision-making: a comparative study of Thai and Australian tourism and hospitality students, $\mathrm{PhD}$ thesis, Victoria University. https://vuir.vu.edu.au/19360/

8) Pathiranage D. (2021). Numerical investigation of dropwise condensation on smooth plates with different wettability, Int. J. Mat. Math. Sci., 3(3), 6073. https://doi.org/10.34104/ijmms.021.060073

9) Proches CNG, Chelin N, Rouvrais S. (2018). Think first job! Preferences and expectations of engineering students in French 'Grande Ecole'. European J. of Engineering Education 43(2), 309325. https://doi.org/10.1080/03043797.2017.1396444

10) R. W., \& Brown, S. D. (1996). Social cognitive approach to career development: An overview. Career Development Quarterly, 44(4), 310- Ler 321. https://eric.ed.gov/?id=EJ529063

11) Rosen, L.S., Paolillo, J.G.P. and Estes, R.W. (1982) 'An Empirical Analysis of Career Choice Factors Among Accountants, Attorneys, Engineers, and Physicians', Accounting Review, 57(4), 785. 48 .

http://www.na-businesspress.com/jhetp/demagalhaes web.pdf

12) Sami HM, Fardous L, and Ruhit DS. (2021). Portfolio optimization in DSE using financial indicators, LSTM \& PyportfolioOpt, Int. J. Mat. Math. Sci., 3(4), 74-84. https://doi.org/10.34104/ijmms.021.074084

13) Shumba, A., Naong, M. (2012). Factors Influencing Students' Career Choice and Aspirations in South Africa. J Soc Sci, 33(2), 169-178. https://doi.org/10.1080/09718923.2012.11893096

14) Simona Demel, Petr Mariel, Jürgen Meyerhof (2019). Job preferences of business and economics students, International J. of Manpower, 40(3), pp. 473-499. https://doi.org/10.1108/IJM-09-2017-0249

Citation: Lutfunneher. (2021). An analysis on the job preference of Jatiya Kabi Kazi Nazrul Islam University students, Int. J. Mat. Math. Sci., 3(4), 85-100. https://doi.org/10.34104/ijmms.021.0850100 @ @ 